\title{
A SWORD SCABBARD CHAPE WITH A DEPICTION OF A BIRD OF PREY FROM THE SURROUNDINGS OF KOSTRZYN
}

\author{
SPRZĄCZKA Z POCHWY MIECZA \\ Z WIZERUNKIEM DRAPIEŻNEGO PTAKA Z OKOLIC KOSTRZYNA
}

\begin{abstract}
In 2016, an Early Medieval sword scabbard chape was handed over to the Museum of Kostrzyn Fortress. According to the person submitting it, it was found about 5-6 years earlier in the northern part of Kostrzyn nad Odrą. The main decorative motif of the openwork field is a heraldically arranged bird. The closest analogies to the chape in question are dated to the second half of the 10th and 11 th century. Artefacts of this type could have been produced in Scandinavia, but also in the Rus and Baltic areas. Unfortunately, we are not able to say what raw material was used to cast the artefact in question. An analysis of the metal composition of the find carried out on the surface of the artefact demonstrated that a very heterogeneous lead alloy was used, which could have also been a result of lead-bleaching. The same technology was also observed on the chapes from Ruthenia. Scholars have explained the presence of an ornithomorphic motif on the surface of the artefact in various ways.
\end{abstract}

Keywords: Kostrzyn, chape, Early Middle Ages, Scandinavia, Rus, Byzantium.

Until recently, findings of Early Medieval sword scabbard chapes, that is, decorated fittings of their lower ends, were rare, if not unusual in present-day Poland (see Janowski 2006). For the past few years the number of discoveries has increased dramatically, which seems to be a result of activity of detectorists (Janowski 2012, p. 7; for new finds see Wyrwa and Janowski 2014; Engel 2015; Kotowicz and Fedyk 2015; Siwiak 2015; Strzyż and Ziętek 2015).

On 17 March 2016 an extremely interesting artefact - an Early Medieval sword scabbard chape - was handed over to the Museum of the Kostrzyn Fortress. According to the submitting person - Mr Ireneusz Nalewajczyk, the artefact was

* Muzeum Archeologiczne Środkowego Nadodrza w Zielonej Górze z siedzibą w Świdnicy, ul. Długa 27, 66-008 Świdnica, arche9@wp.pl.

** Muzeum Twierdzy Kostrzyn, ul. Graniczna 1, 66-470 Kostrzyn nad Odrą, krzysztofsocha@ onet.pl. 
found about 5-6 years ago in the northern part of Kostrzyn nad Odra (Drzewice or Szumiłowo - quarters of the town). Unfortunately an exact location of the find place is unknown, which significantly lowers the scientific value of the artefact. Archaeological sites from the Early Medieval Period have not been known from the area in question so far. It should be emphasized that this is the first known sword scabbard chape from the Middle Odra River Region (see Sikora 2003; Janowski 2006).

The artefact was probably made of copper alloy, which is indicated by the presence of greenish patina on it, with silver shining in some places. It now measures $6.8 \mathrm{~cm}$ in height, with a width of $4.3 \mathrm{~cm}$ and a thickness of $1.0 \mathrm{~cm}$. The artefact weighs $26 \mathrm{~g}$. The main decorative motif of the openwork field is a heraldically arranged bird. Its body, the fanned-out tail feathers and the spread wings beside the body are shown in the frontal view, while the head is portrayed in profile. This depiction is located on both sides of the artefact. Similarly, the two sides of the fitting, in the lower part, and just below the shape of the bird, are decorated with a single band of regular concentric rings (circa 29-30). Additional, single "eyes" occur at the centre of the bird's body and at its peak. Just above this part of the motif there was a hole for fixing the chape. The top part of the fitting is surmounted with a stylized bird head. The artefact is quite well preserved, only on the ornamental side, one of the wings of the bird is missing.

There are more than 50 such finds in Europe, including artefacts ornamented with concentric circles and those with no such ornament (Fig. 4). Fifty years ago, two papers were published, which fundamentally clarified the current knowledge concerning this part of weaponry (Korzuhina 1950; Paulsen 1953). The closest parallels relate the analysed artefact with what was described by Peter Paulsen (1953, p. 22-34) as a Scandinavian group of chapes with a Germanic bird motif, in particular with Type I.2.d. According to this researcher, this type included Swedish-Varangian specimens. Three years before that, Gala Fedorovna Korzuhina (1950) proposed a classification of artefacts of this kind, and finds of that form were included in Type I. In typologies proposed by Vytautas Kazakevičius (1998, pav. 2) and Przemysław Sikora (2003), the find in question represent Type Ia, or Type B-1-1 according to the classification proposed by Natalja's Eniosova (1994, p. 100-121). In the latest study by Fedir Androshchuk (2014a, p. 116), finds of this form are included in Type 3a. It should be emphasized that the researchers who proposed these typologies did not consider the presence of the eyelet decoration as a factor which would be relevant for the classification and chronology. The most up-to-date list of artefacts of this kind was provided by F. Androshchuk (2014a, p. 269-271). However, due to a steady increase in the number of finds, this list needs to be adequately supplemented. The author mentions analogous artefacts found, among others, in Sweden (7), Norway (2), Finland (2), the Baltic states (21) and Eastern Europe (12) (Androshchuk 2014a, Table IV.2). There is no doubt that this list should be completed with new Polish finds (see below), with 


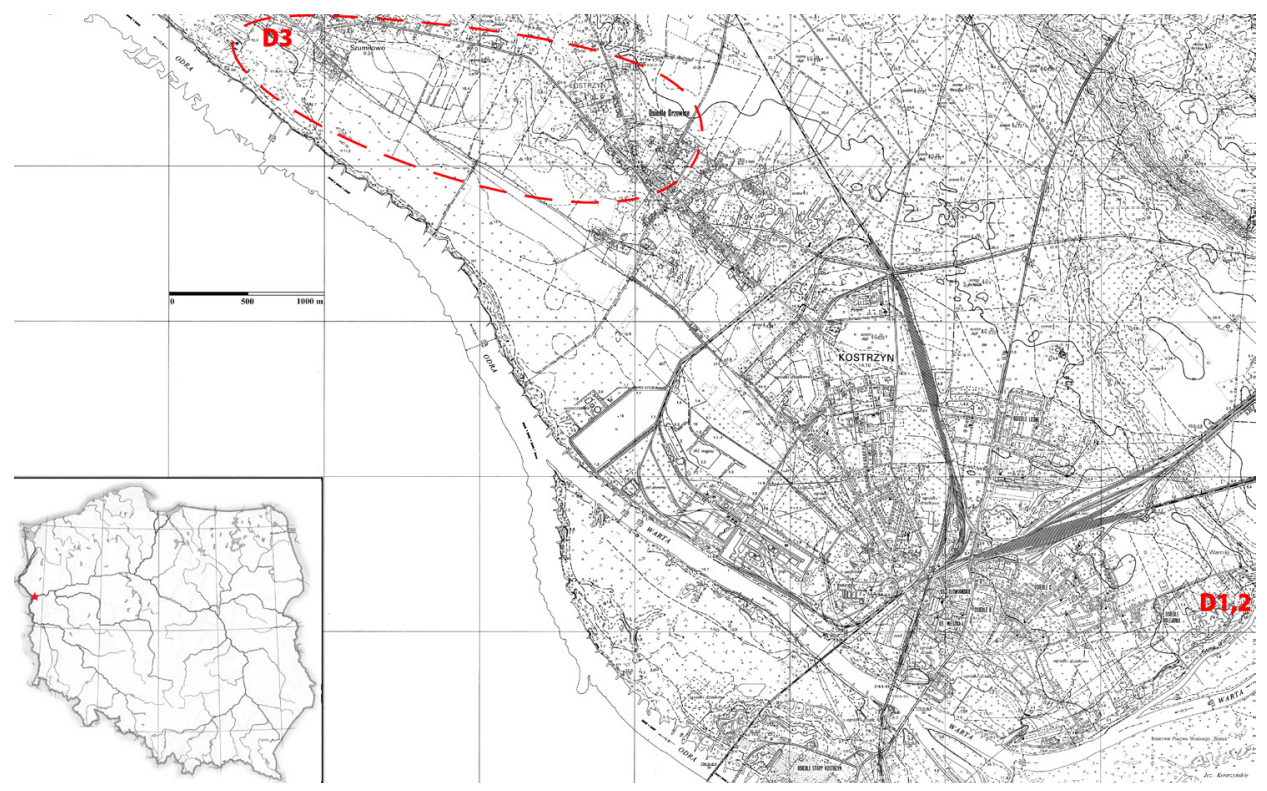

Fig. 1. Possible location of the chape findplace (dashed red line) against the map of Kostrzyn. Findplace of Arab dirhams were marked with D (elaborated by K. Socha)

those from the Latvian cemeteries in Salaspils Laukskola and Izvaltas Brīveri, as well as with those from the Kuldigas district and a private collection (Tomsons 2012, p. 191-192, 102. att. 1-8). One more artefact was found in Eneborg, Saltvik parish in the Aland Islands, Finland. We should also mention here finds from Krusenkien (Mecklenburg-Vorpommern, Germany) and Burg Sand (Lower Austria, Austria) (Posselt 2016, p. 199, P1. 3:5, 5, 6:1). A large part of the artefacts mentioned by him are stray finds. Fortunately, some of these items have well-documented archaeological dating. Finds of this type appeared in the cemetery in Šestovica, Ukraine, dated generally to the first quarter of the 10th-the turn of the 10th and 11th century (Blifel'd 1977, Pl. XV:4; Janowski and Kurasiński 2010, p. 100-101). The chape excavated from Grave 58 was found with a sword of Type H/I. Burial 83 yielded a sword of an analogous type and a Byzantine coin of Leo VI the Wise, dated to 886-912. In Grave 110, a sword of Type V and a dirham were found (Androshchuk 2014a, Table IV.1). A clay mould for the production of chapes of this type from Birka is dated to the second half of the 10th century (Strömberg 1951, p. 237-238). A find from the barrow in the cemetery at Kaup near Mohovoe (Wiskiauten) is dated to the third quarter of the 10th century (Kulakov and Jov 2001, p. 77). Four artefacts of this form discovered in Gnëzdovo, both in the barrow cemetery and the stronghold, cannot be dated to before the mid-10th century (Fig. 4: 9) (Kainov 2009, p. 91). An artefact found during the 
excavation of Troicki Trench 11 in Novgorod should be dated to the 930s (Kainov, Avdeenko 2012, p. 146, Fig. 1:1). A chape of this type was found in Grave 281 of the cemetery in Šokšyno, Mordovia, Russia together with a sword of Type V (?) and coins minted in 933-941 and 940-941 (Androshchuk 2014a, Table IV.1). According to this overview, the chapes of this form appear in Europe in the first half of the $10^{\text {th }}$ century and were in use until the end of this century (Androshchuk $2014 \mathrm{a}$, p. 118), except for the Baltic areas where they also appeared in 11th-century contexts (Fig. 4: 4-7) (Kazakevičius 1992, p. 95, 97).

A later chronology may be attributed to the finds from Poland, where at least 6 analogous chapes are known. The first one is a stray find from the area of the stronghold or accompanying settlement in Skic, Złotów district. It is typologically dated to the $10^{\text {th }}-10^{\text {th }} / 11^{\text {th }}$ century (Fig. 4: 1) (Duchniewski 2002, p. 369-370; Sikora 2003, p. 14; Janowski 2006, p. 26). The second was excavated near the relicts of the rampart of the Early Medieval stronghold in Warszawa-Stare Bródno, Warszawa district (Fig. 4: 2) (Dulinicz 1999, p. 52, pl. 16:1). It was found in layers dated to the 10th-11th century (Dulinicz 1999, p. 51; Sikora 2003, p. 14; Janowski 2006, p. 24). The third artefact was found in the area of the stronghold in Tum near Łęczyca in undisturbed subsoil, outside the main defensive wall, near the axis of the gate passage (Fig. 4: 3). Yet another artefact, but with no ornament of dotted circles, was also found also in this stronghold, in the bottom part of the fill of Feature 180 (Stasiak and Grygiel 2014, p. 182, P1. 10:1-2). The artefacts from Tum were found in layers which were formed during the 11th century (Stasiak and Grygiel 2014, p. 183). The chape from Wolin, typologically parallel, but not decorated with dotted circles, was found in a layer dated to the $4^{\text {th }}$ quarter of the $10^{\text {th }}$ c. (Filipowiak 1955, p. 183; Janowski 2006, p. 26; Stanisławski 2013, Fig. 41:a). The last two artefacts, including one partially preserved, were unearthed last year during a field survey undertaken in the surroundings of Jerzwałd, Iława district.

The closest analogies to the chape in question are the artefacts from Åstad, Oland and Zaljuščik, Russia, which are stray finds (Paulsen 1953, Fig. 21, 24). As said above, other similar artefacts: the clay mould from Birka, and the finds from Gnëzdovo and Tum, are dated to the second half of the 10th and 11th century. On the basis of the above findings, the chronology of the mentioned chape must be determined within the same chronological framework.

Artefacts of this type could have been produced in Scandinavia. This is evidenced by the discovery of the clay mould for casting of this form of chapes in Birka in Sweden (Arne 1913, Fig. 18; Strömber 1951, p. 237-238). Based on the concentration of finds, some scholars also point to the possibility that such chapes were cast in other parts of Europe - in Gotland, in the surroundings of Kiev, in northern Russia, Lithuania and territories between Kiev and the Upper Volga River (Paulsen 1953, p. 33; Kazakevičius 1998, p. 292; Mühlen 1975, p. 37). P. Paulsen described this type as the Scandinavian group; however he did not clearly identi- 


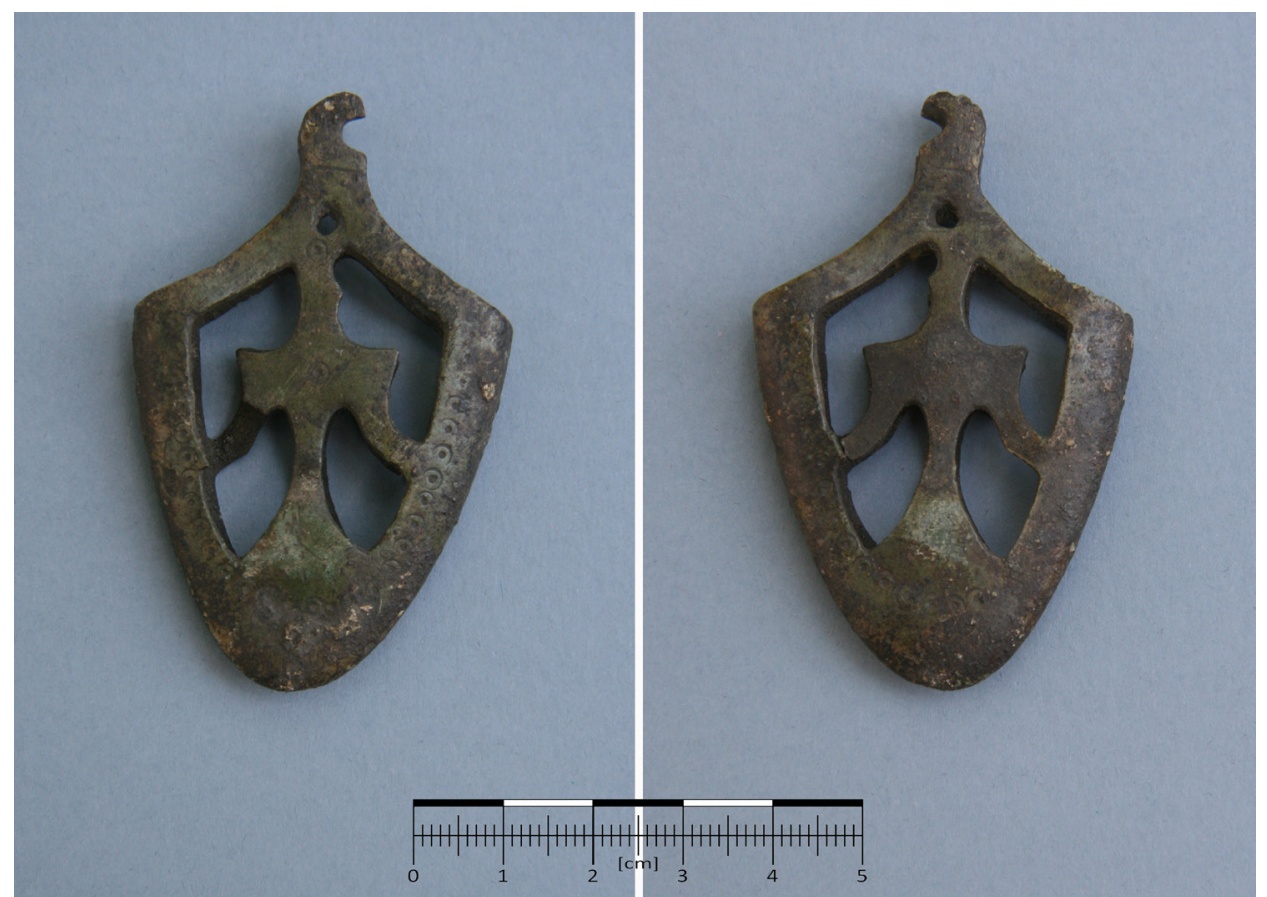

Fig. 2. Sword scabbard chape from the surrounding of Kostrzyn (photo by A. Michalak)

fy the place of their production, but pointed to the high occurrence of the findings in Scandinavia, in particular in Sweden. Berndt von zur Mühlen (1975, p. 38) assumed that they had been made in Gotland and Öland. Similarly, V. Kazakevičius (1992, p. 96-97) considered this type of artefacts from the Baltic areas as Scandinavian imports. As the chapes in this region remain in use in the 11 th century, it cannot be excluded that some of them could be copies made by local craftsmen (Kazakevičius 1998, Fig. 6, 8-9).

Unfortunately, we are not able to say what raw material was used to cast the artefact in question. An analysis of the metal composition of the find (samples were taken from both sides, from the part at the bird's tail), carried out on the surface of the artefact, demonstrated that a very heterogeneous lead alloy was used (Table 1) ${ }^{1}$. These results should be treated with great care. Because of its plastic properties, lead alloy was a rather poor material for the production of such arte-

1 The analysis was carried out by Dr. Patryk Bielecki from the Poznań Science and Technology Park of the Foundation of the Adam Mickiewicz University in Poznań. The surface composition of the artefact was analyzed using a Bruker S1 Titan LE XRF spectrometer equipped with a rhodium anode lamp (Rh) and a silicon drift detector. The measuring instrument uses X-ray fluorescence technology with wave dispersion (WDXRF). 

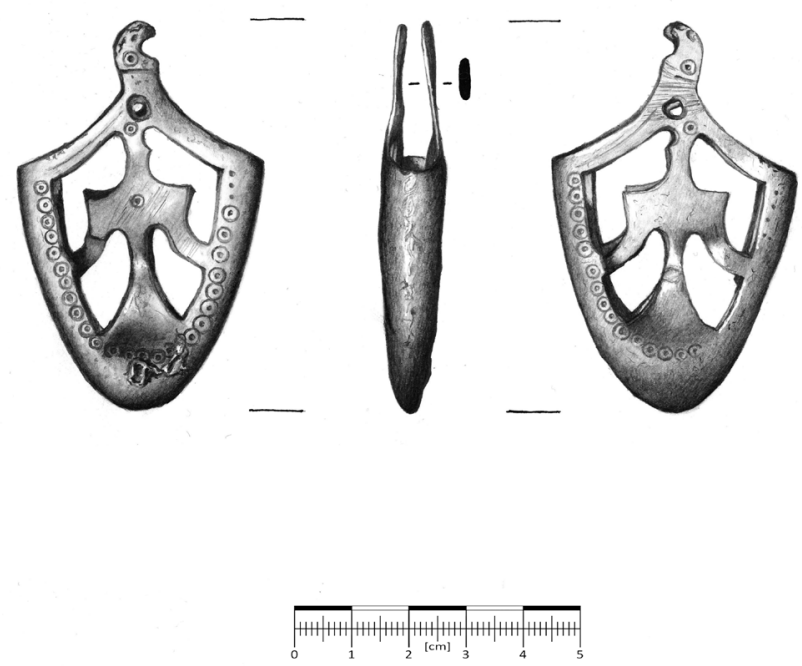

Fig. 3. Sword scabbard chape from the surrounding of Kostrzyn (drawn by J. Sójkowska-Socha)

facts. In addition, it was highly toxic (Hernberg 2000). An XRF analysis of an analogous chape from the Hermitage collection (from the excavations in Kerch in the east of Crimea) has demonstrated that the artefact was cast from gold brass (a copper alloy with 20-25\% zinc) with a slight addition of lead, which did not exceed 1\% (Frenkel' 2002, p. 134). Previous analyses of other types of chapes from Łekno and Nimschütz demonstrated that the artefacts were manufactured from copper alloy with tin. In the case of the first fitting, it has been found out that the material used for its making was an alloy of the following composition: $\mathrm{Cu}-67.43 \%$, $\mathrm{Zn}-14.54 \%$ and $\mathrm{Pb}-9.72 \%, \mathrm{Ca}-3.36 \%, \mathrm{Si}-3.14 \%, \mathrm{Sn}-1.01 \%, \mathrm{P}-0.70 \%$, $\mathrm{Fe}-0.10 \%$ with traces of $\mathrm{Na}$ and $\mathrm{O}$ (Wyrwa and Janowski 2014, Fig. 11). Similar fittings from Nimschütz are made of bronze, containing about $90 \%$ copper, about $5 \%$ tin, about $5 \%$ lead, about $0.5 \%$ zinc and $0.001 \%$ silver, and trace amounts of silicon, aluminium, iron, magnesium and calcium (see Coblenz 1985, p. 300). Until recently we knew that two artefacts from Gnezdovo at Dnieper, Russian Federation, belonging to V. Kazakevičius' subtype Ia, were made of leaded bronze with more than 1\% of lead content (Ениосова 1994, 109; Kainov 2009, 105, przyp. 22, Ris 5:1-2). Accidentaly found chape from Melnik, in Podlachia, was also recently analysed. Its analysis showed that it was made of tin-leaded bronze of following composition: $\mathrm{Cu}-73,8 \%, \mathrm{Sn}-9,53 \%, \mathrm{~Pb}-8,78 \% ; \mathrm{Zn}-6,61 \%, \mathrm{Ag}-$ $0,3 \%, \mathrm{Fe}-0,28 \%, \mathrm{Au}-0,18 \%, \mathrm{Ni}-0,15 \%, \mathrm{Al}-0,11 \%, \mathrm{As}-0,10 \%, \mathrm{Ti}-0,09 \%$, $\mathrm{Cr}-0,06 \%$ (Śnieżko, Kotowicz, forthcomming). Let us note that one of the wings 
Table 1. Results of XRF analysis of sword scabbard chape from Kostrzyn (elaborated by P. Bielecki, A. Michalak)

\begin{tabular}{|c|c|c|c|c|}
\hline \multirow{2}{*}{ Element } & \multicolumn{2}{|c|}{ Sample 1 } & \multicolumn{2}{c|}{ Sample 2 } \\
\cline { 2 - 5 } & concentration [\%] & stddev [\%] & concentration [\%] & stddev [\%] \\
\hline $\mathrm{P}$ & 1.16 & 0.04 & 1.52 & 0.11 \\
\hline $\mathrm{Fe}$ & 4.42 & 0.36 & 5.23 & 1.18 \\
\hline $\mathrm{Ni}$ & 0.01 & 0.03 & 0.2871 & 0.0526 \\
\hline $\mathrm{Cu}$ & 17.91 & 0.29 & 23.57 & 0.67 \\
\hline $\mathrm{Zn}$ & 2.56 & 0.07 & 2.78 & 0.07 \\
\hline $\mathrm{Ag}$ & 0.03 & 0.05 & 0.04 & 0.06 \\
\hline $\mathrm{Cd}$ & 0.40 & 0.02 & 0.24 & 0.03 \\
\hline $\mathrm{Sn}$ & 2.85 & 0.06 & 5.47 & 1.36 \\
\hline $\mathrm{Pb}$ & 70.61 & 0.65 & 61.07 & 1.79 \\
\hline $\mathrm{Mn}$ & & & 0.05 & 0.05 \\
\hline
\end{tabular}

of the bird from the Kostrzyn chape is clearly broken, which also indicates a considerable hardness of the metal from which it was made. The damages of the artefact would have looked much different if it had been made of lead. Perhaps the explanation of the mysterious composition lies in the nature of the analysis which was carried out. It only covered the surface of the analysed artefact. It cannot be ruled out that the analysed artefact was lead-bleached, as indicated by the presence of silvery-gray spots on the surface. Getting pigment from lead has been known since at least the $4^{\text {th }}$ century BC (Holey 1909, p. 2). The method of obtaining white, referred during the Middle Ages as cerosa, is given also by the monk Teophilus (1979, chapter XXXVII, De cerosa et minio). The mystery of this compositition can be finally solved thanks to recently published analysis of the 10th-century chape of untypical form, found in Usvyaty, Pskov oblasti, Russia. It revealed that this artefact was casted from leaded bronze $(81,36 \% \mathrm{Cu}$ and $18,58 \%$ $\mathrm{Pb}$ ), however its outer surface was coated with lead of almost $53 \%$, with much smaller content of copper $(31,4 \%)$ and tin $(11,36 \%)$. Macroscopic study of type Ia chape from Gnezdovo has shown the presence of „white metal”, probably lead on the outer surface (see Kainov 2009, p. 85, fotnote 6). The same procedures S. Kainov observed on five other chapes with depiction of bird of prey from Ruthenian lands (stray finds from Pskov oblast', Ivanovsk oblast' and southern part of Kaluga oblast' in Russia as well as accidentaly found chapes from the area of Belarus and former Birjuli, Mogilev oblast, Belarus). Two first artefacts were analysed with using XRF-analyser. The core of the chape from Pskov oblast' was made of leaded bronze, however it was coated with thin layer of lead alloy, with $33-59 \% \mathrm{~Pb}$ concentration. Similarly artefact from Ivanovsk oblast' was cast from 


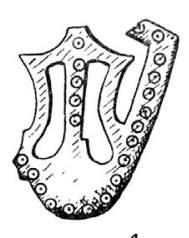

1

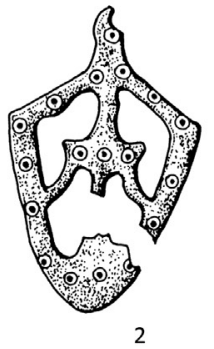

2
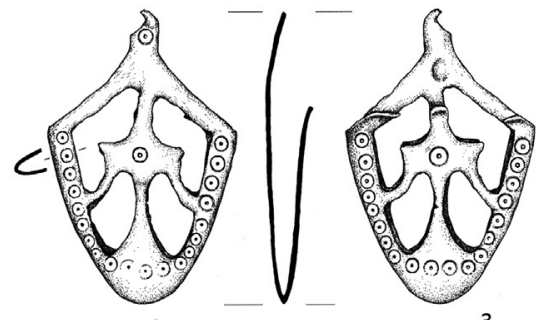

3
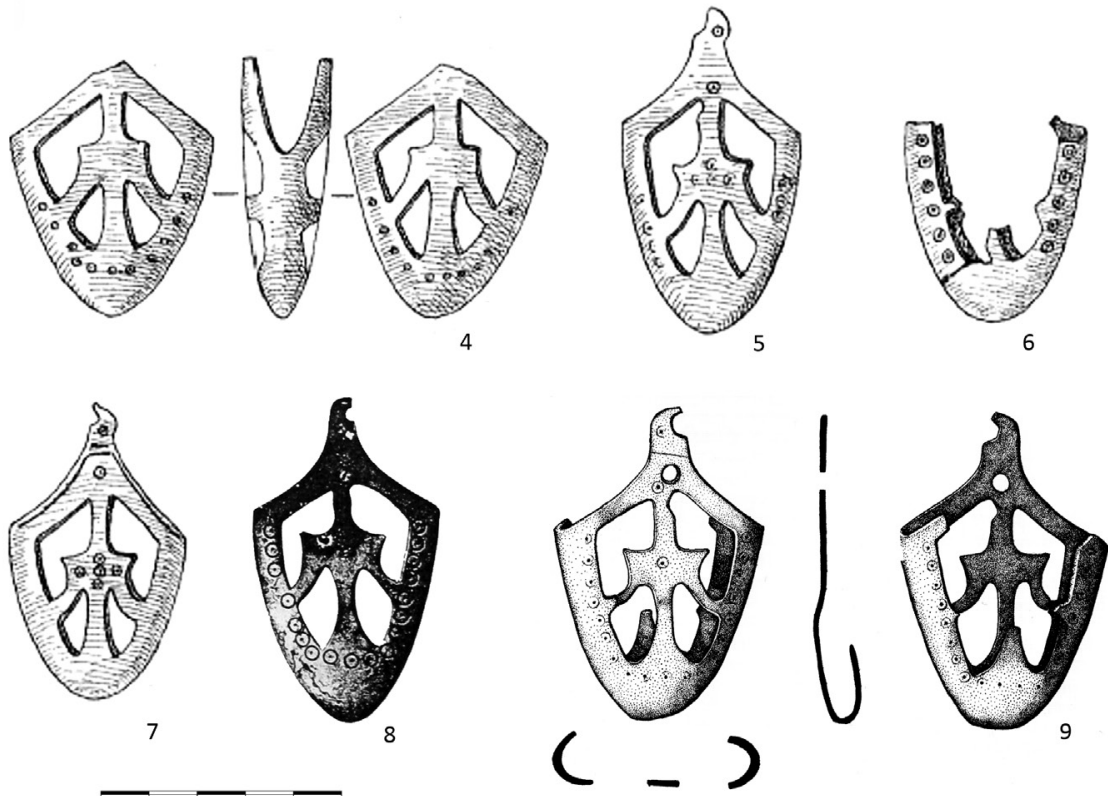

Fig. 4. Parallel chapes to the artefact from the surrounding of Kostrzyn: 1 - Skic, Poland, 2 - Warszawa-Stare Bródno, Poland; 3 - Tum, Poland, 4 - Paragaudis, Lithuania, 5 - Pavirvytè-Gudai, Lithuania, 6 - Asuote, Lithuania 7 - Araišiai, Lithuania, 8 - Zaljuščik, Russia, 9 Gnëzdovo, Russia (after 1-2 after Janowski 2006; 3 after Stasiak and Grygiel 2014; 4-7 after Kazakevičius 1998; 8 after Paulsen 1953; 9 after Kainov 2009)

leaded bronze and then covered with copper alloy of $9-24 \% \mathrm{~Pb}$. The coating gave chape silver-like look and also protected, in significant degree, this item from adverse weather conditions. S. Kainov (2015, p. 626-630) claimed that this kind of Bronze artefacts were rather characteristic for the Viking Age Rus finds, unlike the Scandinavian artefacts with higher amount of zinc. In light of the results of recent analysis of the finds from Ruthenia, it is necessary to re-examine the composition of the chape from Kostrzyn, also taking its interior parts into consideration. 

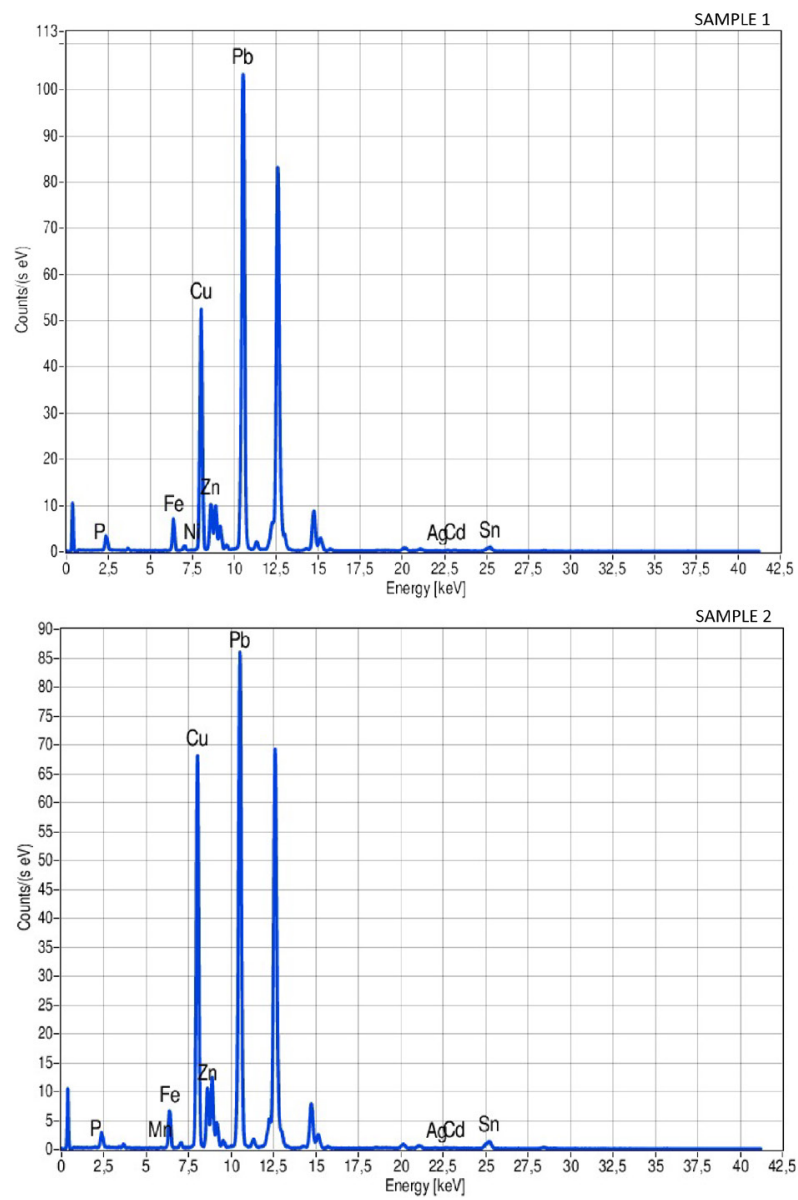

Fig. 5. XRF spectra for analysed chape with identified particles (elaborated by P. Bielecki)

One should remember that artefacts of this type, in addition to practical functions, that is, securing the sword point, could have also served as a social status determinant, due to the decorative character and symbolic references contained therein (Janowski 2006, p. 23). It could have been a peculiar talisman protecting the owner of the sword and securing his success in battle (Janowski and Fudzińska 2006, p. 403). Scholars have explained the presence of an ornithomorphic motif on the surface of the artefact in various ways. Birds of prey played an important role in the beliefs and art of all Germanic peoples, including the Scandinavians (Paulsen 1953, p. 156; Kulakov and Markovets 2004). The eagles, the falcons and the crows were very much appreciated. The Father of the Gods - Odin, could take the form of an eagle and thus wander the world. A similar description 
appears in the Poetic Edda in the context of Odin's wife - Frigg and Freya (Stupecki 2003, p. 102, 265, 273). P. Paulsen (1953, p. 156-175) identified the depiction from the chape as an image of a falcon and linked it with a myth of the fall of the gods in Ragnaroqk (see Jesch 2002, pp. 263-264). Referring to the opinions of ornithologists, Björn Ambrosiani (2001, p. 12) considered birds from chapes, as hawks or falcons (hunting birds of prey),. He believed that these birds were the symbol of the ruling dynasty of Uppsala, who considered themselves heirs of Odin. This motif appears on other Late Viking Age artefacts, but was particularly popular in the art of Scandinavian Rus', which copied patterns from the Scandinavian Peninsula (Duczko 2014, p. 211-214). This symbol could have expressed ties joining Varangian mercenaries remaining in the service of Rus' princes with Scandinavia (Ambrosiani 2001, 21). This would also involve the adaptation of the motif of birds of prey by Rurik and his heirs in the early days of the Rus' state. Many scholars believe that the symbol of early Rurikids - the Tryzub - is in fact a schematised image of a falcon (Paulsen 1953, 166; Ambrosiani 2001, p. 21; Lindberger 2001; cf. Duczko 2004, p. 228-238).

Błażej Stanisławski (2013, p. 210) related this motif to the cult of Odin, referring to the images from Gotlandic picture-stones, which were also mentioned by other researchers (Duczko 2014, p. 211). According to this scholar, the eagle is related to the "upper world" and was at the same time a symbol of militancy. The motif of the eagle was a symbol of the power of the state in the ancient world. It was extremely popular in the Roman Empire, and was widely adopted by states formed after its fall. It must have been a generally accepted and recognizable ideological motif since it appears both on Scandinavian and early Rus' coins (Paulsen 1953, Fig. 234; Lindberger 2001; Duczko 2014, Fig. 10.10).

Andrzej Janowski considered the stylized images of birds as two ravens of Odin, which brought him information from the world (Janowski and Fudzińska 2006, p. 403). The ravens prophesized the success on the battlefield, and their emergence was a reliable sign of victory. According to sources, the Vikings often fought under the banner of the crow (Słupecki 1998, p. 160-165).

Furthermore, one cannot exclude a relation between this motif and the beasts of battle. These are inseparably linked with descriptions of warfare in the literature of the Germanic circle. In Scandinavian poetry there were three beasts of battle, which were present at the fall of the warrior. These were the eagle, the raven and the wolf. These consumers of dead bodies symbolize the grim finality of human death and the triumph of victors on the battlefield (Jesch 2002, p. 251). In skaldic tales there are many examples of the motif of a victorious warrior as the provider of a meal for these beasts (Jesch 2002, p. 254-257). Some men-at-arms are called there Feeder of birds/On bloody corpses (Jesch 2002, p. 260).

Ture Arne (1913, p. 382) came to a conclusion that the bird symbol on scabbard chapes had an eastern origin. The distribution of chapes of Type $3 \mathrm{a}$ and similarly decorated specimens of Type $3 b$ according to Androshchuk (2014, p. 116) addi- 


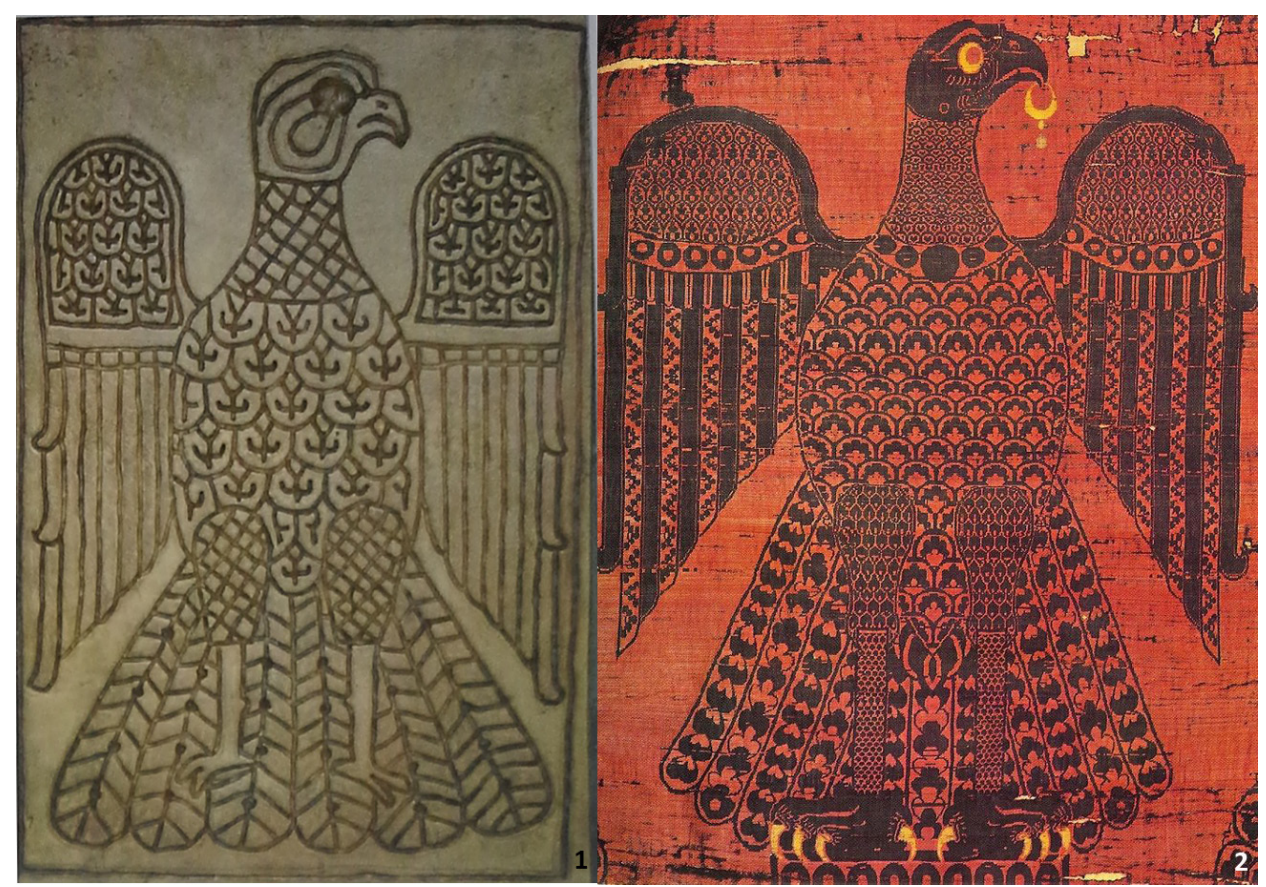

Fig. 6: 1 Byzantine metal panels of the door from the Church of San Paolo fuori le Mura in Rome, dated to approximately 1070 AD; 2 the Eagle Silks from Cathedral Treasury in Brixen from circa $1000 \mathrm{AD}$, made most likely in imperial workshops in Constantinople (after Bollók 2010, Fig. 2)

tionally supports this idea. This scholar emphasizes the presence of chapes with this motif in graves from Kiev and Šestovica, where they are accompanied by artefacts of Byzantine and Hungarian origin (Blifel'd 1977, p. 147, 164, 175; Movtjan 2004). This may indicate that they are a testimony that some Scandinavians arrived there after return from their stay in the Byzantine Empire ${ }^{2}$. The design of heraldic bird chapes of Type $3 a$ and $3 b$ could have been a kind of Scandinavian imitation of the Byzantine imperial eagle, as maintained by Androshchuk (2014, p. 124). This motif was extremely popular in Byzantium, where it was a heritage of the Roman Age. Depictions of such eagles are known from the territory of the Eastern Empire, just to mention here only Byzantine metal panels of the door from the Church of San Paolo fuori le Mura in Rome, dated to approximately $1070 \mathrm{AD}$ (Fig. 6:1), the Eagle Silks from the Cathedral Treasury in Brixen from circa $1000 \mathrm{AD}$, made most likely in imperial workshops in Constantinople (Fig. 6: 2) (Bollók 2010, Fig. 2). In the opinion of F. Androshchuk (2014a,

2 Returns of the Scandinavians from their stay in Byzantium are confirmed by the written sources (Grierson 1967; cf. Androshchuk 2014b). 
p. 122) these were "probably signs of powerful Scandinavian families involved in war and trade expeditions in the East. They could also mark Scandinavian persons who lived permanently in the east". This theory seems probable.

We should bear in mind that animal depictions could have been used in a variety of meanings in various contexts and we should beware of relating particular meanings to contexts which do not support those meanings (Hawkes 1997, p. 319-320).

So far, such artefacts have been treated as Scandinavian imports in the literature. This cannot be ruled out regarding the fitting in question. How did the artefact arrive in the Middle Odra Region? The strategic location of Kostrzyn at the confluence of two rivers: the Odra and the Warta, made it an important trade centre in the Middle Ages (Wyrwa 1991, p. 61). This is indicated by coin finds, including dirhams (Socha 2015). As Ingmar Jansson (1987, p. 791) rightly observed, chapes were rather not the subject of trade or gifts but reflected the presence of the Scandinavians in Central and Eastern Europe. It seems that the presence of Scandinavian mercenaries cannot be excluded here. The number of artefacts of Scandinavian origin found in the Middle Odra River area constantly increases. Beside artefacts discovered in Santok, Gorzów district, both before (Brachman and Unverzagt 1936, p. 91-93, Abb. 14: 3a-b) and after World War II (Zamalek-Monczak 2013, pp. 269-272), we should also mention a recently published find from Grodziszcze, Świebodzin district (Michalak 2017). Some scholars have also related a silver figurine of an armed horseman (part of the hoard from Lisów, dated to the $11^{\text {th }}$ century) to the Vikings (Williams, Pentz and Wemhoff 2014, Cat. 56). Moreover, one cannot forget the pre-war find of an S-type sword from Nowa Wioska, Świebodzin district, which is dated to the 10th-first half of the 11th century. The ornamentation of its hilt no doubt follows to Vikings patterns (Pudło 2014). Let us also remember on Ruthenian relations of analysed chape, visible mostly in its technology. Existence of the artefacts from this milieu in the materials from the middle Odra river area has been also noted in the literature (Michalak, Sadowski 2012, p. 307).

It seems that the lack of finds of bronze chapes in the Middle Odra River Region has been the result of both the state of archaeological excavations in this area and most likely local differences in funeral rites that may have disregarded the provision of weapons to the dead (Michalak and Sinkowski 2017). The role of this area in the structure of the First Piasts' State is also important. Insignificant occurrence of graves with weapons and equestrian equipment or, in a broader sense, dense settlement in this area is explained by considering this part of the Piast state as a buffer zone, which protected the centre of the realm from invasions from the West. Large spaces of high plains, difficult to pass due to dense forests, were reinforced with natural obstacles (rivers and lakes) and were supposed to play a defensive role (Kurnatowscy 2006, p. 92). Under such conditions it was not necessary to deploy significant armed forces in this territory. 


\section{ACKNOWLEDGEMENTS}

We are indebted to colleague Mikko Moilannen, $\mathrm{PhD}$ from Lahti, Finland and Mr Kacper Martyka MA from the Museum of Warmia and Masuria in Olsztyn for the information about new finds of chapes of this type. We would also like to thank Dr hab. Andrzej Janowski from the Institute of Archaeology and Ethnology of the Polish Academy of Sciences, Szczecin Branch for his help with accessing hardly available literature. We would also like to express Our gratitude to dr Piotr N. Kotowicz from Historical Museum in Sanok for sharing unpublished draft of his paper. Last but not least we would like to thank dr Sergei Kainov from State Historical Museum in Moscow for his information on Ruthenian chapes with leaded coating.

\section{BIBLIOGRAPHY}

\section{Sources}

Theophilus

1979 Theophilus: On Divers Arts, translated by J.G. Hawthorne and C.S. Smith, New York: Dover Publications.

\section{Scholarship}

Ambrosiani B. 2001, The Birka Falcon, in: B. Ambrosiani ed., Excavations in the Black Earth 1990-1995. Eastern Connections Part One: The Falcon Motif, Stockholm: Birka project for Riksantikvarieämbetet, p. 11-27.

Androshchuk F. 2014a, Viking Swords. Swords and Social aspects of Weaponry in Viking Age Societies, Stockholm: National Historical Museum.

- 2014b, Rus' and Byzantine Contacts of Scandinavia in $11^{\text {th }}-14^{\text {th }}$ Centuries, Stratum plus. Archaeology And Cultural Anthropology, 5, 199-212.

Arne T. 1913, Einige Schwert-Ortbänder aus der Wikingerzeit, in: Opuscula Archaeologica Oscari Montelio Septuegenario Dedicato, Stockholm: Holmiæ, in ædibus I. Hæggstrœmii, p. 375-390.

Blifel'd D.I. 1977, Davnjorus 'ki pam 'jatky Šestovyci, Kyiv: Akademija Nauk Ukrajins'koji RSR. Instytut archeolohiji.

Bollok A. 2010, The birds on the braid ornaments from Ramakaz. A view from the Mediterranean, in: F. Daim, J. Drauschke, Byzanz - Dar Römmereich im Mittelalter, Teil 3: Peripherie und Nachbarschaft, Mainz: Verlag des Römisch-Germanischen Zentralmuseums, p. 331-368.

Brachmann A., Unverzagt W. 1936, Zantoch. Eine Burg im deutschen Osten, Leipzig: Hirzel Verlag.

Coblenz W. 1985, Slawische Siedlungsreste in Nimschütz, Kr. Bautzen (mit einem Exkurs über vergleichbare Befunde von Pannewitz), Arbeits- und Forschungsberichte zur Sächsischen Bodendenkmalpflege, 29, s. 227-312.

Duchniewski B. 2002, Niektóre trzewiki pochew mieczy z terenu Polski-mity i rzeczywistość, „Archeologia Polski", 47/1-2, p. 368-373.

Duczko W. 2004, Viking Rus: studies of the presence of Scandinavians in Eastern Europe, Leiden: Brill.

- 2015, Status and Magic. Ornaments Used by the Bodzia Elites, in: A. Buko ed., Bodzia. A Late Viking-Age Elite Cemetery in Central Poland, Leiden-Boston: Brill, p. 202-221. 
Dulinicz M. 1999, Trzewik pochwy miecza z Warszawy-Starego Bródna (ze studiów nad zabytkami z wczesnośredniowiecznego Mazowsza), „Światowid” 42, Nowa Seria 1/B, p. 51-58.

Engel M. 2015, Wczesnośredniowieczny trzewik pochwy miecza z miejscowości Stulichy, pow. Wegorzewski, „Acta Militaria Mediaevalia” XI, p. 173-180.

Eniosova N.V. 1994, Azhurnye nakonechniki nozhen mechej konca X-XI vv. na territorii Vostochnoj Evropy, in: Ju. L. Shhapova ed., Istorija i evoljucija drevnih veshhej, Moskva: Izd-vo Moskovskogo universiteta, p. 100-121.

Filipowiak W. 1955, Sprawozdanie z prac wykopaliskowych $w$ Wolinie $w$ latach 1953-1954, „Sprawozdania Archeologiczne" 1, p. 179-193.

Frenkel' Ja.V. 2002, O nahodke azhuroj buteroli severoevropejskogo kruga, in: D.A. Machinskij ed., Ladoga i Severnaja Evrazija ot Bajkala do La-Mansha. Svjazujushhie puti i organizujushhie centry. Shestye chtenija pamjati Anny Machinskoj, Staraja Ladoga: Staroladožskij istoriko-arh. i arheolog. muzej-zapovednik, p. 134-137.

Grierson Ph. 1967, Harold Hardrada and byzantine coin types in Denmark, in: P. Wirth ed., Polychordia. Festschrift Franz Dölger zum 75. Geburtstag, Amsterdam: Hakkert, p. 124-138.

Hawkes J. 1997, Symbolic lives: the visual evidence, in: J. Hines ed., The Anglo-Saxons from the Migration Period to the Eight Century: An Etnographic Perspective, Woodbridge: Boydell Press, p. 311-344.

Hernberg S. 2000, Lead Poisoning in a Historical Perspective, American Journal of Industrial Medicine 38 , p. 244-254.

Holley C.D. 1909, The Lead and Zinc Pigments, New York: Wiley.

Janowski A. 2006, Brazowe i srebrne trzewiki pochew mieczy z X-XIII w. z terenu Polski. Uwagi o proweniencji i datowaniu, „Acta Militaria Mediaevalia” 2, p. 23-50.

- 2012, Trzewiki pochew miecza pochodzenia bałtyjskiego znalezione na wspótczesnych ziemiach polskich, „Pruthenia” VII, p. 7-35.

Janowski A., Fudzińska E. 2006, Trzewik pochwy miecza z miejscowości Podzamcze koło Kwidzyna, „Pomorania Antiqua” XXI, p. 395-409.

Janowski A., Kurasiński T. 2010, Miecz i pochwa - razem i osobno. Wstęp do problematyki, in: $\mathrm{P}$. Kucypera, P. Pudło, G. Żabiński eds, Arma et Medium Aevum. Studia nad uzbrojeniem średniowiecznym, Toruń: Wydawnictwo Adam Marszałek, p. 74-115.

Jansson I. 1987, Communication between Scandinavia and Eastern Europe in the Viking Age. The archaeological evidence, in: K. Düwel et all eds, Untersuchungen zur Handel und Verkehr der vor- und frühgeschichtlichen Zeit in Mittel- und Nordeuropa, Göttingen: Vandenhoeck \& Ruprecht, p. 773-807.

Jesch J. 2002, Eagles, ravens and wolves: beasts of battle. Symbols of victory and death, in: J. Jesch ed., The Scandinavians. From the Vendel Period to the tenth century. An etnographic perspective, Woodbridge: Boydell Press, p. 251-271.

Kainov S.Ju. 2009, Nakonechniki nozhen mechej iz Gnezdova, „Acta Militaria Mediaevalia” V, p. 79-110.

- 2015, Nakonechnik nozhen mechej i fragment kol'cebidnoj bulavki iz Usvjata, in: I.I. Eremeev ed., Drevnosti Polockoj zemli v istoricheskom izuchenii vostochno-baltijskogo regiona (ocherki srednevekovoj arkheologii i istorii Pskovsko-Belorusskogo pob'in'ja), Sankt-Peterburg, pp. 626-630.

Kainov S. Ju., Avdeenko E. E. 2012, Litye nakonechniki nozhen mechej (po materialam Troickogo raskopa Novgoroda Velikogo), Arkheogicheskie Vesti, 18, pp. 145-151.

Kazakevičius V. 1992, Sword chapes from Lithuania, in: A. Loit, E. Magurçviès, A. Caune eds, Die Kontakte zwischen Ostbaltikum und Skandinavien im frühen Mittelalter, Stockholm: Centre for Baltic Studies, University of Stockholm, p. 91-107.

- 1998, Iš vélovojo geležies amžiaus Baltu ginklų istorijos (kalaviju makštu galu apkalai), „Lietuvos Archeologija" 15, p. 297-332.

Korzuhina G.F. 1950, Iz istorii drevnoruskogo oružija XI veka, „Sovetskaja Arkheologija” 13, p. 63-94.

Kotowicz P.N., Fedyk R. 2015, Wczesnośredniowieczny trzewik pochwy miecza z okolic Sanoka, „Acta Militaria Mediaevalia" XI, p. 235-236.

Kulakov V.I. 2005, Die wikingerzeitliche Siedlung und das Gräberfeld Kaup bei Wiskiauten. Bericht über die Ausgrabungen der Jahre 1956-2004, Offa 59/60, p. 55-79. 
Kulakov V.I., Jov O.V. 2001, Nakonečniki nožen meča iz kurgana 174 mogil’nika Kaup i s gorodišča Franopol', „Kratkie Soobščeniâ Instituta Arheologii” 211, p. 77-84.

Kulakov V.I., Markovets M.Ü. 2004, Birds as companions of Germanic gods and heroes, „Acta Archaeologica" 75 , p. 179-188.

Kurnatowscy Z. i S. 2006, Piastowskie „urządzanie” kresów pótnocno-zachodnich państwa, in: M. Dworaczyk et all eds, Świat Stowian wczesnego średniowiecza, Szczecin-Wocław: Wydawnictwo Instytutu Archeologii I Etnologii PAN, p. 91-99.

Lindberger E. 2001, The Falcon, the Raven and the Dove. Some bird motif on medieval coins, in: B. Ambrosiani ed., Excavations in the Black Earth 1990-1995. Eastern Connections Part One: The Falcon Motif, Stockholm: Birka project for Riksantikvarieämbetet, p. 29-86.

Michalak A. 2017, Zabytki ruchome z badań na terenie kompleksu grodowego w Grodziszczu (stan. 1) z lat 1963-1964, in: B. Gruszka ed., Grodziszcze. Od grodu plemiennego do kluczowego ośrodka zachodnich rubieży państwa wczesnopiastowskiego. Studium interdyscyplinarne, Zielona Góra: Oddział Lubuski Stowarzyszenia Naukowego Archeologów Polskich (forthcomming).

Michalak A., Sadowski K. 2012, Kolejny staroruski zabytek z Polski zachodniej? Pochodzenie przęślika z Radzynia $w$ świetle badań petroarcheologicznych, in: A. Jaszewska, Z najdawniejszych dziejów. Grzegorzowi Domańskiemu na pięćdziesięciolecie pracy naukowej, Zielona Góra: Wydawnictwo Fundacji Archeologicznej, p. 305-312.

Michalak A., Sinkowski S. 2017, An Ottonian spur from the Early Medieval cemetery in Santok in Western Poland, „Acta Militaria Mediaevalia” XIII, pp. 133-147.

Mihajlov K.A., Nosov E.N. 2002, Novye nahodki nakonechnikov nozhen mechej na Rurikovom gorodishhe, Arheologicheskie Vesti, 9, p. 136-140.

Movtjan I.I. 2005, Royal guard grave in Kiev, Olga \& Ingegerd. Vikingafurstinnor I öst. Statens Historiska museum, 2004-2005, p. 54-56.

Mühlen von zur B. 1975, Die Kultur der Wikinger in Ostpreußen, Bonner Hefte zur Vorgeschichte, 9, p. 2-274.

Paulsen P. 1953, Schwertortbänder der Wikingerzeit. Ein Beitrag zur Frühgeschichte Osteuropas, Stuttgart: Kohlhammer.

Posselt N. 2016, Die spätslawische Schwertortbänder aus Mecklenburg und Vorpommern, in: F. Biermann, T. Kersting, A. Klammt, Die frühen Slawen - von der Expansion zur gentes und nationes, 2. Teilband, Langenweissbach: Beier \& Beran Archäologische Fachliteratur, p. 193-220.

Pudło P. 2014, What do we really know about the sword from Nowa Wioska in Świebodzin district?, „Archeologia Środkowego Nadodrza” XI, p. 195-201.

Sikora P. 2003, Frühmittelalterliche Ortbänder bei West- und Ostslawen. Versuch einer typologischchronologischen Einordnung, ,Zeitschrift für Archäologie des Mittelalters” 31, pp. 11-38.

Siwiak W. 2015, Wczesnośredniowieczny trzewik pochwy miecza z lasu Turska Dąbrowa nad Notecia koło Bydgoszczy, „Pomorania Antiqua” XXIV, p. 401-410.

Słupecki L.P. 1998, Wyrocznie i wróżby pogańskich Skandynawów: studium do dziejów idei przeznaczenia u ludów indoeuropejskich, Warszawa, Wydawnictwo Instytutu Archeologii i Etnologii PAN.

- 2003, Mitologia skandynawska w epoce Wikingów, Kraków, Nomos.

Socha K. 2015, Wczesnośredniowieczny gród w Kostrzynie nad Odra - mity i fakty. Przyczynek do dyskusji, in: A. Jaszewska, A. Michalak ed., Woda - żywioł ujarzmiony i nieujarzmiony, VII PolskoNiemieckie Spotkania Archeologiczne, Janowiec, 24-25 maja 2012 r., Zielona Góra, Oddział Lubuski Stowarzyszenia Naukowego Archeologów Polskich, p. 211-229.

Stasiak W., Grygiel R. 2014, Pozostałe materiały ruchome, in: R. Grygiel, T. Jurek eds, Poczatki Łęczycy 2. Archeologia o początkach Łęczycy, Łódź, Muzeum Archeologiczne i Etnograficzne w Łodzi, p. 182-223.

Strömberg M. 1951, Schwertortbänder mit Vogelmotiven aus der Wikingerzeit, Meddelandenfrån Lunds Universitets Historiska Museum 1950-1951, p. 221-243.

Strzyż P., Ziętek J. 2015, Okucie pochwy miecza z Przybyszyc, „Acta Militaria Mediaevalia” XI, p. 236-237.

Śnieżko G., Kotowicz P.N. (forthcomming), Nietypowy trzewik pochwy miecza z Mielnika na Podlasiu, Acta Militaria Mediaevalia, XIV.

Tomsons A. 2012, Divasmeņu zobeni Latvijas arheologiskajā materiālā 9.-13.gs., Rīga (PhD typescript, Latvijas Universitāte in Riga). 
Williams G., Pentz P., Wemhoff M. eds. 2014, The Vikings. Life and Legend, London, British Museum Press.

Wyrwa A. 1991, Prahistoria i wczesnośredniowieczne dzieje społeczeństw zamieszkujących okolice Kostrzyna nad Odra, in: J. Marczewski ed., Kostrzyn nad Odrą. Dzieje dawne i nowe, Poznań, Instytut Zachodni, p. 37-76.

Wyrwa A., Janowski A. 2014, Dolne okucie pochwy miecza z przedstawieniem ludzkiej twarzy z Łekna (stan. E5), „Fontes Archaeologici Posnanienses” 50/2, p. 323-346.

Zamelska-Monczak K. 2013, Traces of Viking culture in Santok, in: S. Moździoch, B. Stanisławski, P. Wiszewski eds. Scandinavian Culture in Medieval Poland, Interdisciplinary Medieval Studies, Volume II, Wrocław: Wydawnictwo Instytutu Archeologii i Etnologii PAN, p. 267-277. 